\title{
Revisiting the Kazakh Famine at the Beginning of the 1930 in Fine Art Forms from the Perspective of Cultural Memory
}

\author{
Dilyara Safargaliyevna Sharipova', Ainur Berikovna Kenjakulova², Svetlana \\ Zhumasultanovna Kobzhanova³, Kaldykul Serikbaevna Orazkulova ${ }^{4}$ \& Leila \\ Abdyganievna Kenzhebayeva \\ ${ }^{1,2}$ Institute of Literature and Art named after M. Auezov of the Science Committee of the \\ Ministry of Education and Science of Kazakhstan, Almaty, Kazakhstan. \\ ${ }^{3}$ A. Kasteyev State Museum of Arts of the Republic of Kazakhstan, Almaty, Kazakhstan \\ ${ }^{4}$ Kazakh National Academy of Arts named after T.K. Zhurgenov, Almaty, Kazakhstan \\ ${ }^{5}$ Kazakh National Academy of Arts named after T.K. Zhurgenov, Almaty, Kazakhstan
}

\begin{abstract}
Reflecting on the past is the foundation for national unity. In this context, it appears relevant to conduct research into fine art as storage of memory and a resource for the reconstruction of lasting images of the past. This article looks at the issue of cultural memory in Kazakhstan through the study of works of figurative art devoted to the history of the famine of the beginning of the 1930s. The authors examine how this topic was reflected in Soviet art, as well as at the current stage of cultural development. The forms of representation of cultural trauma as a metaphor and an affective experience are also explored in the article. Nowadays, monuments of grief perform socio-cultural functions that are inextricably connected with the development of national identity.
\end{abstract}

Keywords: monument, sculpture, famine, communicative memory, cultural memory, commemoration, nomadism, identity.

\section{Introduction}

Formation of an integral perception of past events has become one of the main research directions in European countries over recent decades. As far as the study of cultural memory is concerned, the greatest challenge is posed by interpretation of tragic events of the national history, such as Asharshylyk - a terrible famine in Kazakhstan at the beginning of the 1930s. According to the most conservative estimates, it claimed the lives of over 2 million people, i.e. $40 \%$ of the indigenous population.

Starting from the 1920s, Kazakhstan was subject to huge political and socio-economic transformations. Modernization forcefully imposed on enormous territories of nomadic livestock farming led to the creation of industrial giants and destruction of the traditional economic system. Nomads were forced to lead a settled way of life by collectivization - destruction of private farms and their unification into kolkhozes (collective farms).

All the produce of kolkhozes was taken by the government as compulsory supplies of cattle and grain. The methods used were administrative pressure on the management of kolkhozes and repression traditional for the Stalin regime. It is a known fact that by February

(C) AesthetixMS 2020. This Open Access article is published under a Creative Commons Attribution Non-Commercial 4.0 International License (http://creativecommons.org/licenses/by-nc/4.0/), which permits non-commercial re-use, distribution, and reproduction in any medium, provided the original work is properly cited. For citation use the DOI. For commercial re-use, please contact editor@rupkatha.com. 
1932, $87 \%$ of collective farms and $51.8 \%$ of individual farmers had totally lost their livestock (Naselenie Kazakhstana, 1917-1939). Having lost livestock, the inhabitants of the steppe were deprived of their traditional diet based on milk and meat. At the end of the 1920s, there was a series of severe droughts and high cattle mortality due to the icy condition of roads. In winter of 1930 famine started.

In the Soviet period, Asharshylyk (Kazakh for "famine") sank into oblivion in the official history. After Kazakhstan gained independence, the process of reflection on this catastrophe started and has not been completed.

The tragedy of the famine is at the center of the novel "The Lonely Yurt" (1989) by S. Yelubay and the documentary narrative "The Chronicle of Great Jute" (1990) by V. Mikhaylov. The play "Jute" written by the Russian author O. Zhanaydarov is successfully running in Kazakh theaters. The documentaries "Asharsylyk" (2013) by E. Rakishev, "Zulmat: Genocide in Kazakhstan" by Zh. Mamay, and "Nomads of the Kazakh Steppe" (2019) by D. Satpaev and the short fiction film "A Handful of Grain" (2019) by B. Mustafaev focus directly on the issue of the famine. Taking into account regular public contracts for historical novels, films, and plays, this is a pitifully minuscule share.

As far as modern painting, graphic art, and contemporary art practices are concerned, there is not a single work reflecting this topic. In the light of insufficient attention to the collective trauma of the Soviet past in Kazakh modern art, the responsibility for the commemoration of Asharshylyk was assumed by monumental art. In Kazakhstan, there are three monuments devoted to the victims of the famine of the 1930 .

The identified commemorative practices are viewed as instruments for the commemoration of the memory of these events. The prospective concepts of memory, traditions, oblivion, places of memory, and cultural trauma developed by M. Halbwachs (1980), P. Ricouer (2004), J. Assmann (2004) and A. Assmann (2014, 2016), P. Nora (1999), and J. Alexander (Alexander, Eyerman, Giesen and Neil 2019; Alexander 2013) are important for comprehension of modern art in general, as well as for analysis of different types of art.

The main concept used in this research is that of cultural memory developed by Jan and Aleida Assmann. It is the memory of historical events constructed in the national space that analyzes the past in the interests of the current socio-political situation. It should be distinguished from communicative memory existing within a social group, which embraces quite a short historical period, "it is typically restricted to 80-100 years, spanning three-four generations, meaning that this memory is embodied by its carriers who find new usages of it" (Assmann 2004, p. 50). As far as more long-term periods are concerned, in order to preserve the past through rituals, monuments, books, and the media, social memory institutions are used: archives, museums, and universities (Assmann 2004, p. 59). This is when the transition to the cultural memory level takes place.

Cultural memory allows departing from another concept - historical memory - which restricts memories by establishing a monopoly of the ruling elite on the past. Among diverse forms of cultural representation of history, figurative art still plays a special role. Dialogue with the past as reflection and constructing history through visual images are important components of cultural history. 


\section{Methods}

In order to achieve the set goal, we used a range of methods in the sphere of art studies. Stylistic analysis allowed us to identify the most significant formal and ideological characteristics of the works under examination. The comparative historical method enabled us to draw analogies between different monuments as forms of commemoration. Considering sculptural compositions through the prism of semiotics as signature city areas served as a prerequisite for the analysis of the influence of public moods and ways of formation of cultural memory. Advances in the sphere of memory studies were also employed in the course of this research. It is an interdisciplinary field that examines the interconnection between the past and the present in the socio-cultural context.

\section{Results and Discussion}

Totalitarian states were trying to impose a certain official version of the historical past on the population. The history of the famine of the 1930 s was a forbidden subject during the Soviet epoch. Looking at the list of compulsory topics, for which artists received contracts with the state and created paintings and sculptures for exhibitions devoted to certain dates of the Soviet history (anniversary of the October Revolution, establishment of the Kazakh Autonomous Socialist Soviet Republic, anniversary of the Victory in Great Patriotic War, etc.), one can see that the topic of collectivization is missing there (Shorthand report of the 3rd Artists' Congress, sheets 2-18). Moreover, the very motive of nomadism was considered unreliable. If painters, poets or writers referred to the value system of nomads, their ethical code, the concept of an aul (a Kazakh village) as a single family, sacralization of nature, or even portrayal of the everyday routine, it was instantly treated to nationalism and praising the previous regime.

For example, the first professional painter A. Kasteev was accused of not depicting changes in the Soviet rural areas, such as mechanization of production, usage of electricity, new buildings of clubs and schools, in his paintings. It led to the conclusion that A. Kasteev's art did not comply with the norms of socialist realism, "Looking at these works, it is difficult to say that it is modern Soviet painting. In the old times, there were such pastures as well" (Tematicheskii plan respublikanskoi khudozhestvennoi vystavki 1952 goda, sheet 200).

The conclusion made by E. Hobsbawm and people of similar views about the total influence of power on the content of the collective memory of society is also valid for understanding the processes of constructing history in Soviet Kazakhstan (Hobsbawm, Ranger T, 1983). However, communicative memory shared by artists and their contemporaries resulted from their personal experience and was bright and distinct, but remained within the boundaries of conversations about the past in the family and with close friends.

The topic of Asharshylyk was indirectly reflected in book illustrations to literary works describing jute (mass mortality of cattle due to adverse weather conditions in the steppe that led to epidemics and famine). In the 1970s, for graphic artists, M. Kisamedinov's and T. Mukatov's works devoted to this topic became a narration about traumatic events faced by their families.

T. Mukatov, who created illustrations to the novel "The Path of Abai" by M. Auezov, used the biblical motive of the Deposition from the Cross. The man's body is falling from a horse like from the cross where Christ was crucified and in the center of the composition, there is a crying woman. Twisted arms, tensely clasped fingers, face distorted by pain, mouth half-opened in a silent scream - the image of the mother here is close to the image of Virgin Mary on the altars of 
the Northern Renaissance, reproducing the features of ars nova, where unconcealed pain, suffering, and physiological manifestation of emotions helped to perceive the depth of the depicted grief. A small illustration becomes one of the instruments of returning the eliminated processes back to history by means of narration about their victim, inducing a very strong emotional response to the events described in the novel.

The picture "The she-camel mourning the death of her baby" (1978) from the "Jute" series by $\mathrm{M}$. Kisamedinov also engaged the audience in hard work of their memory. The graphic image of the she-camel is very similar to monumental sculpture. There are no soft free lines, the body curves are rough and angular, the outlines resemble a black spot gripped in a vice of a white sheet. The image is perceived as a metaphor for helplessness. The author chose the position of the she-camel perfectly: her head thrown back, crooked neck, large volume squeezed into a rectangle of a paper sheet - all this creates a feeling of total loneliness. Having appeared in an exhibition, this work became a big event in the cultural life of Kazakhstan discussed not only by artists, but also by writers and actors. As we see it, the picture had such great resonance because the depicted scene encouraged the audience to look for symbolic meaning and became true "lieu de mémoire" in P. Nora's terminology. This historian identified two types of such places: firstly, memorials erected in commemoration of a certain event where people come to remember about those; secondly, there are places that keep authentic memories as such, "places of refuge, sanctuaries of instinctive devotion and hushed pilgrimages" (Nora, 1999, p. 27). The graphic work by M. Kisamedinov encouraged work of memory and made the terror that spread together with stories about collectivization behind closed doors tangible.

In 1997, May 31 was declared the Day of Remembrance of Victims of Political Repression. Over recent years, three Asharshylyk monuments have been erected: in Nur-Sultan (2012), Pavlodar (2012), and Almaty (2017). In modern Kazakhstan, monuments devoted to the famine have the same compositional structure - portrayal of mother and child. All three monuments follow the traditions of Soviet monuments: they represent large-scale sculptures in a realistic style put on a pedestal and, thus, separated from the surroundings. The Soviet monument also established the traditions of choosing straightforward solutions for the imagery used in all monuments: famine - death - dead people. The monument in Nur-Sultan was erected as a result of a national contest, while monuments in Almaty and Pavlodar were created at the direction of the city administration, which definitely affected their artistic features.

The Monument to the Victims of the Famine (2012) in Nur-Sultan (architect: O. Alibaev, sculptor: V. Pirozhkov) represents a ground with figures of mother and child in the center surrounded by an arch wall symbolizing the carcass of a Kazakh yurt. The sculptors created a composition that is similar to a stage in a theatre. The expressive acuteness of the mother's image and its accentuation by its size are not supported by architectural solutions. The neutral background of the Wall of Grief - a semicircular black stele - are not connected with the focus on strong emotions shown by the central sculpture. It appears that the organization of the micro ensemble also looks eclectic and unjustified. The more abstract, "wired" figure of the mother is in discord with the round sculpture of son and gravestones symbolizing the Kazakh people. The mother's gesture raising her hands to the sky, which is extremely important for the meaning of the memorial, can be hardly identified, since the attention is diverted by flabby gesticulation of her hands, which look like spider's tentacles.

In the monument erected in Pavlodar in 2012, the sculptor M. Abylkasym depicted a crying child next to the wizened body of the dead mother. The author explained the harshness of the employed images and the outright naturalism of the sculpture by the huge scale of the tragedy. As 
we see it, this message is fundamentally wrong. It leads to sculptural kitsch, unjustified exaltation, and artificial unnervedness. More often than not, these techniques are used to distract the audience from formal drawbacks of the sculpture.

The monument to victims of famine in Almaty designed by young graduates of the Art Academy (D. Usenbaev, A. Burkitbaev, and K. Beguliev) was erected in 2017 without a contest and received a negative appraisal of the professional community.

A sculpture commemorating such an important historical event requires preliminary work on the topic conducted by the creator and a high degree of generalization of certain events and emotions in order to reach a new level of figurative impact on the audience. This is what makes it a monument, i.e. a large-scale art memorial that is supposed to exist for a long time. On no account should it be a bronze figurine increased in size. The lack of "flesh" cannot be justified by the topic of famine. For example, the ruined image of the sculpture "Falling Warrior" by Henry Moore hits the target, since he designed it as an architectural building, whose parts are falling apart, leaving only ruins on the pedestal. This ruined form allowed using this sculpture, which was not connected with a particular topic by the author, as a monument to the victims of war in the German town of Goslar.

As far as the monument to the victims of Asharshylyk is concerned, the bodies of sculptures are not ruined - they just were not molded in detail. It appears that the sculptors have no idea of the body structure or the laws of molding shapes. So, the mother and child transformed into two skeleton-like mannequins.

Summarizing the description of the above-mentioned works, it should be mentioned that the authors keep using the module of the traditional monument, but deviate from the academic sculptural traditions in terms of focusing on emotions, which was previously unacceptable.

The strategies of involving spectators in history through extreme emotional distress used by the Kazakh sculptors are nowadays actively employed in architecture, museum space, and theater. A spectator becomes a participant of a certain activity, where they comprehend the offered information and meanings not rationally, but rather physically. A brilliant example of this approach is the Jewish Museum in Berlin designed by D. Libeskind, where history is reconstructed predominantly by means of feelings dictated by the architecture. Passing through the first corridor of the museum, visitors gain new physical experience - going along the way of suffering. The floor goes up, making it very difficult for visitors to go forward. One of the corridors takes a visitor "to an absolutely dark room three stories high and there is nothing there apart from faces carved from metal. Smoldered human features just piled up, like coins at the bottom of a trunk. A powerful space. I remember no other piece of architecture that I would leave in such a neurotic condition. This space has meaning. This meaning is life - lives of those who passed away and those who stayed alive" (Revzin 2008).

Such experience of creating monuments of grief has not been used in Kazakhstan yet. The authors of the monuments described above are at the first level of comprehension of the historical tragedy. The traumatic image of Asharshylyk is covered at the level of the subject. At the same time, the authors hope to achieve acuteness of perception and to establish communication with the external world, which was lost by traditional Soviet monuments.

As J. Alexander wrote, "Cultural trauma occurs when members of a collectivity feel they have been subjected to a horrendous event that leaves indelible marks upon their group consciousness, marking their memories forever and changing their future identity in fundamental and irrevocable ways" (Alexander, Eyerman, Giesen and Neil 2019). Shocking images reflecting the distortion of the normal course of life are becoming a new type of representation of the Kazakh 
history as an event that inflicts a visual "wound" on the spectator, thus engaging them in active dialogue.

A few factors impede the successful implementation of this sculptural program. The first factor is a very low formal level of the work and lack of an integral sculptural image. Secondly, sculptors carry on working within the canon of the Soviet monument fraught with certain associations. J. Young, a researcher of the Holocaust memorials and monuments erected in Germany starting from the 1980 s, insists that usage of traditional monuments in commemoration of the topics of genocide and war victims is unacceptable, since such memorials are successors to the monumental art typical of Nazism and Stalinism. Besides, according to J. Young, ordinary monuments work with memory in an absolutely wrong way, "instead of embodying memory, such memorials may only displace memory. These artists fear rightly that to the extent that we encourage monuments to do our memory work for us, we become that much more forgetful. They believe, in effect, that the initial impulse to memorialize events like the Holocaust may actually spring from an opposite and equal desire to forget them" (Young 1999). From this perspective, it is also important to take into account the modern practice of creating memorials by a certain date urgently, often against the clock, when the result of work is meant to make a fast, but not a longlasting effect instead of relying on an elaborate ideological program and its sculptural implementation. Short terms translate into the inability to create multiple figure compositions and achieve the effect of a narration.

Finally, the very location of the monuments weakens their symbolic message. It is extremely important to choose the right environment for a monument devoted to death and suffering of people. For this purpose, the monument should be easy to notice and be located in an equally significant place. In Nur-Sultan, it was installed in quite a small area next to the entrance to the park in close proximity to residential buildings. In Pavlodar, such a monument was erected on a highway and in Almaty, it was hidden on a small ground in a park surrounded by tall trees.

Pathos and open display of grief in the examined sculptural works are also based on deep reasons rooted in the self-identity of the Kazakh people.

The tradition of zhoktau - wailing over a dead person - is very important in Kazakh culture. People sing about the fate that has befallen the family, the irreparable loss, and the good deeds of the dead person in an expressive manner that stirs up emotions. At the same time, in the course of zhoktau, the traumatic condition is transformed into an aesthetic experience. The epic aspect is strongly developed in zhoktau, when personal grief acquires a cosmic scale, becoming grief of the whole clan. Zhoktau can also be perceived as a cultural metaphor for the attitude of this ethnic group to tragic events - they comprehend and forgive the past through wailing.

In connection with usage of sculptural imagery as representation of extreme experience, it is worth mentioning different types of cultural memory suggested by J. Assmann by analogy with C. Levi-Strauss's methodology of "hot", dynamic, and "cold" societies (Assmann 2004, pp. 72-73).

"Hot" cultural memory is oriented towards dynamics and development. Focusing on the turning points, ups and downs, it can influence political changes. The narrative of the national past as a time full of ecstatic tragic experiences represented by monuments to victims of famine, which can be characterized as "hot" memory, is giving way to the historical narrative portraying the past as an idyllic picture of nomadic life and heroic deeds. Hence active erection of equestrian statues devoted to heroes, batyrs of the 18th century, who protected the Kazakh land during the Dzhungarian invasion. Mythologization of history characteristic of the present time can be clearly traced in these monuments. It is a type of historical consciousness when history is conveyed through memory keepers - historical figures. They are endowed with qualities of cultural heroes 
that protect the land from destruction and chaos. The glorification of certain people involves the visualization of history and depiction of legendary characters as ones really present in the urban landscape. From this perspective, equestrian statues perform protective functions, emphasizing the integrity of the Kazakh territories.

In J. Assmann's typology, this type of cultural memory is called "cold". "Cold" memory conserves dates and names, depriving them of the current nerve, which also encourages the preservation of the existing political regimes.

The perception of the memory of Asharshylyk by other ethnic groups in Kazakhstan is a controversial issue. As opposed to Ukraine, where the Holodomor became the center of historical policy, in Kazakhstan, the topic of famine is treated with concern, since it can put a strain on the relationships between different ethnicities living in the country. From the perspective of nationalist polemics, collectivization in Kazakhstan is interpreted as a follow-up on the imperial policy of Russia that involved resettlement of Russian peasants to Kazakhstan and allocation of the best pastures to them at the turn of the 2oth century. Tsarist bureaucrats and the Bolsheviks treated aborigines as subhuman, which allowed them to send indigenous people to their doom for the good of the country and after the revolution - for the purpose of achievement of socialist future. From this perspective, the famine of the 1930 looks as clearance of territories for further manipulations conducted by the Soviet power, such as the expulsion of peoples and the Virgin Lands Campaign. Due to existence of different versions of interpretation of the past, it is very important to get it across to society that each group of the population should have their own cultural memory and it should not interfere with others. In order to acquire the true identity of Kazakh citizens, other ethnic groups have to recognize and mourn over the terrible events of collectivization, which affected other nationalities. This recognition will by no means destroy the peaceful coexistence of various ethnicities in Kazakhstan and the relations between Kazakhstan and Russia.

An example of a more advanced approach to working through the trauma of famine is a contest project by N. Dalbai, which lost to the project by V. Pirozhkov. This work refers to classical sculpture rather than to monuments of the Soviet era. The sculptor shifts gradually from a sign to a narration. He shows several generations of a family: an old man trying to support the sliding body of his son, his mother chained in drapery, thus being already beyond the boundaries of life, and their grandson, alive and free of the stamp of famine. The group made of the first three figures is self-absorbed, forming a quiet space of sorrow, while the boy looks directly at the spectator, insisting on communication. There are no corpses here - only reserved grief.

This monument calls for the involvement of the audience in history through emotional distress, as well as a certain degree of preparation, being able to decipher religious associations about martyrs through references to the images typical of classical epochs and further reflection. As a result, the monument loses the clear ethnic reference and the grief of the Kazakh people is perceived as universal human grief.

Such monuments help to take the problem of figurative reflection of Asharshylyk to the next level: from a tragedy that happened to Other to compassion and realization of common grief. J. Alexander pointed out that "cultural traumas broaden the realm of social understanding and sympathy, and they provide powerful avenues for new forms of social incorporation" (Alexander 2013, p. 34).

A significant feature of all sculptures under consideration is the selection of the iconographic pattern for portraying famine in the steppe. Sculptors of different nationalities, generations, and art schools showed rare unanimity when they turned to realistic images of 
mother and child at the threshold of death and a vivid depiction of victims of violence exterminated by the totalitarian regime. Therefore, the sculptural images of the Asharshylyk monuments bear an explicit reference to the annihilation of an ethnic group, i.e. genocide.

As opposed to the Ukrainian Holodomor, nowadays, the Kazakh famine is not classified as genocide, although the first committee of Kazakh historians and politicians reached a verdict of genocide as early as in 1992 (Nasilstvennaya kollektivizatsiya i golod v Kazakhstane v 1931- 1933 gg, p. 5). Strategic partnership with Russia determines a reserved appraisal of the famine in Kazakhstan given by national politicians.

The historians that study the subject of famine over the period of collectivization also call for reasonable conclusions. For instance, N. Pianciola believes that the authorities were not going to exterminate certain social or political groups and the famine became the means of "political oppression of the rural population and getting full control of its resources" (Pianciola 2008).

The German researcher R. Kindler is of the same opinion: he insists that while the economic effect of the forced transition to the settled way of life was zero, the social effect was sovietization of Kazakhs, "impoverished Kazakhs under the penalty of death had no choice but to surrender to the Soviet state. The way out of the crisis led to dependence" (Kindler, 2017, p. 264).

S. Cameron, who wrote a book about the Kazakh famine, tends to think that it was cultural genocide that happened as a result of destruction of both the economic and value systems of nomadism. He points out, "The fact that the Kazakh famine does not appear to fit the legal definition of genocide does not make this atrocity less worthy of our attention nor lessen the scale of Kazakhs' suffering. Rather, it should make us rethink why we place so much emphasis on those cases that fit the legal definition of genocide and miss others, such as the Kazakh case, which also stemmed from a political process and were no less destructive to human life" (Cameron 2018, p. 8).

As far as the issue of the status of the famine in Kazakhstan is concerned, the most important thing is to reconstruct the whole picture of the events under consideration. The number of dead people and those who decamped to neighboring countries fleeing from hunger is still not specified. The total number varies from two to five million people.

Prior to the recognition of the Holodomor in Ukraine, thorough investigation and identification of guilty people were organized and huge work with demographic data was carried out, while nothing of that has been done in Kazakhstan.

As a result, cultural memory about the famine of the 1930 s is "capsuled", according to the definition suggested by A. Assmann (2016, p. 243), and transforms into a latent phase, like the traumas of the German civilian population during World War II, which were publicly realized only at the end of the 2oth century.

This leads to an increased number of nationalist statements about collectivization. Living through historical experience as personal drama creates difficulties in the course of working through the trauma and reaching constructive oblivion in Paul Ricoeur's theory, i.e. understanding and forgiveness (Ricoeur 2004).

Apparently, without feeling moral responsibility for the famine and overcoming the cultural trauma, the establishment of a deeper identity among the multinational population of Kazakhstan is impossible. The tragedy of famine, which might not be expressed to the full by any type of art due to certain limitations, requires very delicate and careful treatment. A straightforward appeal to the feelings of the audience and exploiting the emotional response 
equates a monument with a poster or caricature. A memorial to the greatest tragedy should be consciously oriented not only towards feelings, but also to the mind of a spectator, not only instill terror, but also provide knowledge about history, its comprehension and enlightenment.

\section{Conclusion}

Monuments to the victims of the famine of the beginning of the 1930 s are an important form of commemorative practices. However, without an active cultural policy on this issue, further elaboration of this topic by figurative art remains problematic. The main concept of the examined monuments is the representation of a historical event that took place over the period of collectivization as genocide. The whole set of problems connected with sculptural implementation of the topic of famine, the functions of such a memorial, and the ideological program behind the monuments trigger engagement in public discussions of these sculptural pieces, as well as cultural memory in general.

Departure from the rules of traditional monuments towards physiological manifestation of emotions and expressiveness typical of the modern monuments to the victims of famine in the Kazakh steppe represents "hot" cultural memory of painful historical events of the 2oth century, which is being replaced by "cold" memory of the official history represented by heroes of the mythological past.

The shift of sculptors towards conveying strong emotions is taking place within the modern pursuit of the achievement of emotional distress in the description of the history and can be traced back to the tradition of Kazakh crying zhoktau.

Monuments to famine victims in Kazakhstan were installed without due regard to their significance as landmarks in the urban space, contests for their design were not always held, their programs did not stir wide public discussions, which, as we see it, shows the general attitude of the state to preservation of the memory related to the history of the 2 oth century.

Creation of ideologically meaningful urban centers and "places of memory" requires thorough elaboration of material by sculptors, which takes them from flamboyance and univocacy of the used symbols to more complex images, an elevated or, on the contrary, consciously detached register of works, and is perceived by the audience in a contemplative and integral way. There are no such meaningful places in Kazakhstan yet, which prompts specialists in the humanities to accentuate the importance of working through the trauma and collective recognition of the tragic historical events once again.

\section{References}

Alexander, J. 2013. Smysly sotsialnoi zhizni. Kultursotsiologiya [The Meanings of Social Life: A Cultural Sociology]. Moscow: Praxis, pp. 640.

Assmann, A. 2014. Dlinnaya ten proshlogo: Memorialnaya kultura i istoricheskaya politika [The long shadow of the past: memorial culture and memorial culture and historical politics]. Moscow: Novoe literaturnoe obozrenie, pp. 328.

Assmann, A. 2016. Novoe nedovolstvo memorialnoi kulturoi [New discontent with memorial culture]. Moscow: Novoe literaturnoe obozrenie, pp. 232. 
Assmann, J. 2004. Kulturnaya pamyat: Pismo, pamyat o proshlom i politicheskaya identichnost v vysokikh kulturakh drevnosti [Cultural Memory and Early Civilization: Writing, Remembrance, and Political Imagination]. Moscow: Yazyki slavyanskoi kultury, pp. 368.

Cameron S. 2018. The Hungry Steppe: Famine, Violence, and the Making of Soviet Kazakhstan. Cornell University Press, pp. 294.

Halbwachs M. 1980. The Collective Memory. New York: Harper \& Row Colophon Books.

Hobsbawm, E. and Ranger,T. 1983. The Invention of Tradition. Cambridge University Press.

Alexander, J. C., Eyerman, R., Giesen, B. and Neil J. Smelser and Piotr Sztompka. Cultural Trauma and Collective Identity. Journal of the Royal Anthropological Institute, 14: 431-472

Kindler R. 2017. Stalinskie kochevniki: vlast i golod v Kazakhstane [Stalin's Nomads: Power and Famine in Kazakhstan]. Moscow: Politicheskaya entsiklopediya, pp. 382.

Naselenie Kazakhstana v 1917-1939 gg [The population of Kazakhstan in 1917-1939. Date of access: 14.10.2019 www.e-history.kz/ru/contents/view/997.

Nasilstvennaya kollektivizatsiya i golod v Kazakhstane v 1931- 1933 gg. Sbornik dokumentov i materialov [Forced collectivization and famine in Kazakhstan in 1931-1933. A collection of documents and materials]. Introduction and content by K.S. Aldazhumanov, M.K. Kairgaliev, V.P. Osipov, Yu.I. Romanov. (1998). Almaty, pp. 263.

Nora, P. 1999. Frantsiya-pamyat [Realms of Memory: Rethinking the French past]. St. Petersburg: SPBU Publishing House, pp. 328.

Pianciola, N. 2008. The Collectivization Famine in Kazakhstan, 1931-1933. Harvard Ukrainian Studies, 25, 3/4: 237-251.

Revzin G. 2008. Proekt evreiskoi arkhitektury [The project of Jewish architecture]. Date of access: 10.10.2019. www.lechaim.ru/ARHIV/193/revzin.htm.

Ricoeur P. 2004. Pamyat, istoriya, zabvenie [Memory, History, Forgetting]. Moscow: Izdatelstvo gumanitarnoi literatury, pp. 725 .

Shorthand report of the 3rd Artists' Congress. The Central State Archive of the Republic of Kazakhstan. Fonds 1736, series 1, file 461, 260 sheets.

Tematicheskii plan respublikanskoi khudozhestvennoi vystavki 1952 goda [The theme-based plan of the 1952 republican art exhibition]. Fonds 1736, series 1, file 404, 18 sheets.

Young J.E. 1999. Memory and counter-memory. The end of the monument in Germany. Harvard design magazine, 9. Date of access: 10.10.2019. www.harvarddesignmagazine.org/issues/9/memory-andcounter-memory.pdf. 